\title{
https://doi.org/10.46813/2020-130-165 \\ COMPARISON OF SPARK CHANNEL EXPANSION IN HYDROGEN, OXYGEN AND NITROGEN
}

\author{
K.V. Korytchenko ${ }^{1}$, Yu.V. Kashanskyi ${ }^{1}$, O.V. Cherkashyn ${ }^{2}$, D.Yu. Belyuchenko ${ }^{2}$, \\ A.V. Maksimov ${ }^{2}$, A.I. Nikorchuk ${ }^{3}$, P.V. Chernenko ${ }^{3}$ \\ ${ }^{1}$ National Technical University "Kharkov Polytechnic Institute”, Kharkiv, Ukraine; \\ ${ }^{2}$ National University of Civil Defence of Ukraine, Kharkiv, Ukraine; \\ ${ }^{3}$ National Academy of the National Guard of Ukraine, Kharkiv, Ukraine \\ E-mail: korytchenko_kv@ukr.net, \\ omsroot@kpi.kharkov.ua
}

The results of the spark channel expansion simulation in various gases such as hydrogen, oxygen and nitrogen have been presented. Difference in thermodynamic properties of the various gases has been taken into account. Influence of a type of gas on the discharge current, the spark resistance, the energy deposited in the spark and the spark gas-dynamic expansion has been found out. Influence of initial species concentration in mixture of nitrogen, hydrogen and oxygen on detonation initiation by spark discharge has been discussed.

PACS: 52.80.Mg

\section{INTRODUCTION}

A study of a spark channel expansion in various gases, such as hydrogen, oxygen and nitrogen, is of practical interest. This is due to an application of mixtures of these gases with various initial species concentration in the detonation technology where detonation initiation produces by a spark discharge [1]. A separate study of the spark channel expansion in hydrogen, oxygen and nitrogen allows revealing a tendency of a change in the species concentration for the detonation initiation by spark discharge.

It is important to determine the energy deposited into the spark channel and parameters of the shock wave generated by the spark discharge to analyze the detonation initiation process [2]. Also, a study of the process of detachment of the shock wave from the conductive spark channel is required. Investigations of these processes are carried out both theoretically and experimentally [2, 3]. In this work, the study is carried out by numerical modelling.

Numerical models presented in works $[4,5]$ are designed to study the spark discharge evolution. When these models are used to investigate the spark expansion in various gases, it requires taking into account the differences in the thermodynamic and chemical properties of the gases. It is also necessary to take into account the specific features of radiation heat transfer in various gases [6], that requires a huge array of specific experimental data and leads to a significant complication of numerical models. Therefore, in this work, we used a previously developed numerical model of the spark channel expansion in various gases, intended for engineering calculations with an acceptable accuracy, where a consideration of the radiation heat transfer was simplified [7]. The validation of the model was carried out in works [6, 7].

The objective of this study is to compare a spark channel expansion in hydrogen, oxygen and nitrogen.

\section{A NUMERICAL MODEL OF THE SPARK CHANNEL EXPANSION}

Spark channel expansion was simulated by the gas dynamic equations (continuity, momentum and energy) for a dissociating gas expressed as [3]

$$
\frac{\partial \vec{a}}{\partial t}+\frac{1}{r} \frac{\partial(r \vec{b})}{\partial r}=\frac{1}{r} \vec{f},
$$

where vector columns are equal to:

$$
\begin{aligned}
& \vec{a}=\left(\begin{array}{c}
\rho \\
\rho u \\
\rho \varepsilon+\frac{\rho u^{2}}{2} \\
y_{i}
\end{array}\right), \vec{b}=\left(\begin{array}{c}
\rho u \\
p+\rho u^{2} \\
u\left(\rho \varepsilon+\frac{\rho u^{2}}{2}+p\right)+k_{T} \frac{d T}{d r} \\
u y_{i}
\end{array}\right), \\
& \vec{f}=\left(\begin{array}{c}
p \\
r \cdot\left(\sigma E^{2}-Q_{e m}\right. \\
r \dot{\omega}_{i}
\end{array}\right),
\end{aligned}
$$

where $\rho$ is the gas density; $u$ is the velocity, $p$ is the pressure, $\varepsilon$ is the internal energy of gas per the mass unit of gas, $k_{T}$ is the heat conduction coefficient, $E$ is the electric field strength in the discharge channel column, $\sigma$ is the plasma conductivity in the channel, $W_{\mathrm{em}}$ is the discharge energy radiation loss, $r$ is the radial coordinate, $t$ is the time, $T$ is the temperature, $y_{i}$ is the molar concentration of the $i$-th species, $\omega_{\mathrm{i}}$ is the chemical reaction rate of the $i$-th species $\left(\mathrm{O}, \mathrm{O}_{2} ; \mathrm{H}, \mathrm{H}_{2} ; \mathrm{N}, \mathrm{N}_{2}\right)$.

Details of the total numerical model, boundary conditions and the simulation procedure are presented in works [3].

Difference in thermodynamic properties of the various gases was taken into account. So, specific heat capacity $C_{p}{ }^{0}$ at constant pressure, species molar enthalpy $H^{0}$ and species molar entropy $S^{0}$ are defined as: 


$$
\begin{gathered}
\frac{C_{p k}^{0}}{R}=\sum_{m=1}^{M} a_{m k} T_{k}^{(m-1)} ; \\
\frac{H_{p k}^{0}}{R T_{k}}=\sum_{m=1}^{M} \frac{a_{m k} T_{k}^{(m-1)}}{m}+\frac{a_{M+1, k}}{T_{k}} ; \\
\frac{S_{k}^{0}}{R}=a_{1 i} \ln T_{k}+\sum_{m=2}^{M} \frac{a_{m k} T_{k}^{(m-1)}}{(m-1)}+a_{M+2, k},
\end{gathered}
$$

where $a_{m k}$ are coefficients which were taken for various gases [8].

Difference in a molar mass of the various gases was considered in the state equation.

Non-equilibrium chemical kinetics was considered to simulate dissociation/association process in hydrogen, oxygen and nitrogen (Table 1).

Table 1

Reactions, rate coefficients in $\mathrm{cm}^{3}$, mol and $s$ and activation energy in $[\mathrm{cal} / \mathrm{mol}]$

\begin{tabular}{|c|c|c|c|c|}
\hline No. & Reaction & A & $n$ & $E$ \\
\hline 1 & $\mathrm{O}+\mathrm{O}+\mathrm{M} \leftrightarrow \mathrm{O}_{2}+\mathrm{M}$ & $1.2 \cdot 10^{17}$ & -1 & 0 \\
\hline 2 & $\mathrm{H}+\mathrm{H}+\mathrm{M} \leftrightarrow \mathrm{H}_{2}+\mathrm{M}$ & $1 \cdot 10^{18}$ & -1 & 0 \\
\hline 3 & $\mathrm{~N}_{2}+\mathrm{M} \leftrightarrow \mathrm{N}+\mathrm{N}+\mathrm{M}$ & $8.508 \cdot 10^{25}$ & -2.25 & 225 \\
\hline
\end{tabular}

Where $\mathrm{M}$ is a third body $\left(\mathrm{O}, \mathrm{O}_{2} ; \mathrm{H}, \mathrm{H}_{2} ; \mathrm{N}, \mathrm{N}_{2}\right)$.

The rate coefficients were found out by equation

$$
k_{k}=[M] \cdot A_{k} T^{n_{k}} \exp \left(\frac{-E_{a k}}{R T}\right),
$$

where $[M]=\sum_{i} \alpha_{k i}\left[y_{i}\right] ; \quad \alpha_{k i}$ are third-body collisions coefficients for various species (Table 2).

The reverse reaction rate is calculated from the forward rate and the equilibrium constant.

Table 2

Third-body collisions coefficients $\alpha_{k i}$ for species

\begin{tabular}{|l|c|c|c|c|c|c|}
\hline Species & $\mathrm{O}_{2}$ & $\mathrm{O}$ & $\mathrm{H}_{2}$ & $\mathrm{H}$ & $\mathrm{N}_{2}$ & $\mathrm{~N}$ \\
\hline Collisions coefficients & 1 & 1 & 1.7 & 1 & 1 & 1 \\
\hline
\end{tabular}

A local thermal equilibrium model was applied to evaluate the electrical conductivity of gas in the region where the gas temperature exceeds $8000 \mathrm{~K}$. The conductivity of the gas located outside this region was neglected. So, Saha ionization equation was used for the calculation in singly ionized gas (hydrogen) and doublyionized gas (nitrogen and oxygen), where the following degeneracy of states $g_{i}$ for the atoms and ions and ioni-

\begin{tabular}{|c|c|c|c|c|c|c|c|c|c|c|c|c|c|}
\hline & & & & & & & & & & & & & \\
\hline Parameter & $\infty$ & $\begin{array}{r}+ \\
0 \\
0\end{array}$ & $\begin{array}{r}+ \\
0 \\
0\end{array}$ & \$ & $\begin{array}{c}+ \\
0 \\
0\end{array}$ & $a_{\infty}^{2}$ & $\sum_{\infty}^{+}$ & $\begin{array}{l}1 \\
z \\
z \\
0 \\
0\end{array}$ & $\stackrel{+}{0}$ & $\stackrel{+}{ \pm}$ & - \pm & $\stackrel{+}{z}$ & 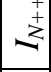 \\
\hline V & 9 & 4 & 9 & 2 & 1 & 4 & 9 & 6 & $\begin{array}{l}0 \\
\ddot{2}\end{array}$ & $\frac{\infty}{n}$ & $\begin{array}{l}0 \\
\dot{1}\end{array}$ & $\stackrel{\Xi}{ \pm}$ & $\begin{array}{l}n \\
\delta \\
0 \\
2 \\
\gamma\end{array}$ \\
\hline
\end{tabular}
zation energy $I_{i}$ were used (Table 3 ).

Table 3

Degeneracy of states and ionization energy in [eV]

A capacitor discharge was investigated. Thus, a series $R L C$-circuit with a variable spark resistance was calculated. A capacitance of $C=0.1 \mu \mathrm{F}$, an inductance of $L=2 \mu \mathrm{H}$ and a circuit resistance of $R_{c}=1 \Omega$ were applied. The charge voltage was $U_{C}=30 \mathrm{kV}$. The total energy was $45 \mathrm{~J}$. A spark gap length was $1 \mathrm{~mm}$. Circuit parameters were the same for various gases.

Energy of $2.2 \mathrm{~mJ}$ was deposited in the region with radius of $0.1 \mathrm{~mm}$ by time of $10 \mathrm{~ns}$ to form a narrow conductive spark channel. Than energy deposition depended on the discharge current.

\section{SIMULATION RESULTS}

A current for discharges in the various gases is presented in Fig. 1. It was found out that the current did not depend significantly on a type of gas for the considered discharge circuit.

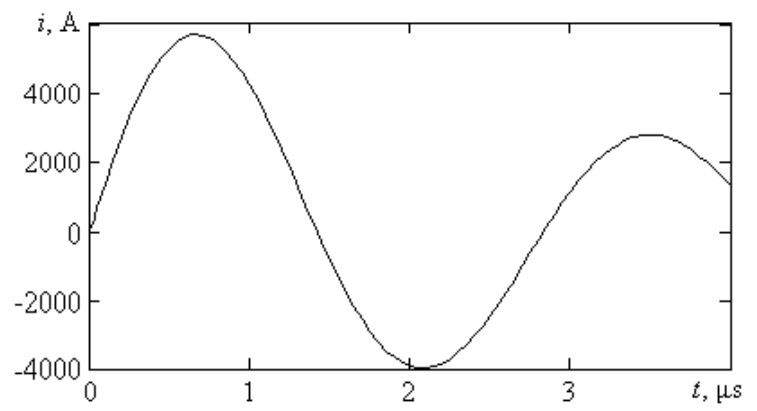

Fig. 1. The discharge current over time for various gases

The similar discharge current happened because the difference in the spark resistance in case of various gases was not high and the average spark resistance was lower than the circuit resistance and the inductive reactance.



Fig. 2. The spark channel resistance over time for discharges in nitrogen (1), hydrogen (2) and oxygen (3)

So, the oscillation period is about $T_{\text {osc }}=2.9 \mu$ s (see Fig. 1). The inductive reactance is $X_{L}=\frac{2 \pi}{T} L \approx 4.3 \Omega$ and the circuit resistance is $1 \Omega$. For comparison, the average spark resistance is about $0.01 \Omega$ (Fig. 2).

The energy deposited in the spark channel over time at the calculated circuit for discharges in nitrogen, hydrogen and oxygen is shown in Fig. 3. It is observed an increased energy deposition for discharge in hydrogen in comparison with discharges in nitrogen and oxygen. The difference is especially high during the first semi period of the discharge.

The energy difference between discharges in hydrogen and nitrogen at $1.4 \mu$ s exceeds $10 \%$ and the difference between discharges in hydrogen and oxygen is about $20 \%$. But during a further spark evolution, the energy difference between discharges in hydrogen and nitrogen reduces. 


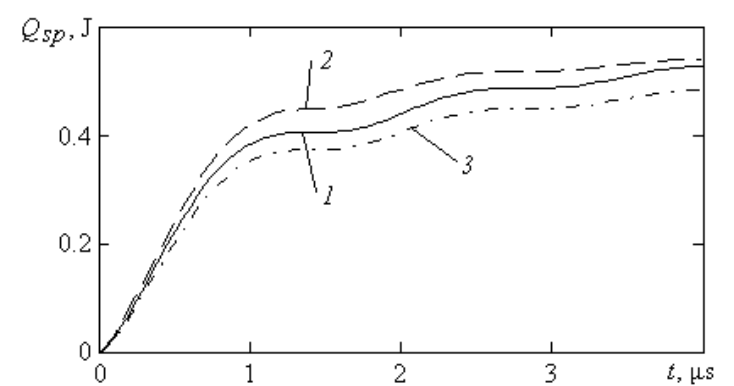

Fig. 3. The energy deposited in the spark channel over time for discharges in nitrogen (1), hydrogen (2), and oxygen (3)

Results of the pressure history into the spark channel for discharge in the various gases are given in Fig. 4.

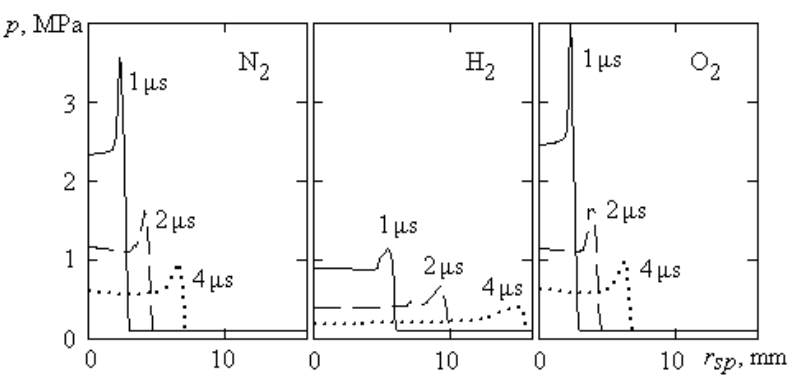

Fig. 4. Distribution of pressure along the radial coordinates at time of 1,2 , and $4 \mu$ sor discharges in nitrogen, hydrogen and oxygen

It is observed that the intensity of a shock wave generated by spark discharge depends on a type of gas. The highest pressure ratio in the shock wave front at the same time corresponds to the spark expansion in oxygen. The lowest pressure ratio is exceeded for the discharge in hydrogen. So, a maximum of the pressure is about $4 \mathrm{MPa}$ at time of $1 \mu \mathrm{s}$ for the discharge in oxygen and the maximum is about $1.2 \mathrm{MPa}$ at such a time for the discharge in hydrogen. According to the gasdynamics theory, the pressure rise $\Delta p$ at the intensive shock wave is calculated by an equation

$$
\Delta p=\frac{2}{\gamma+1} \rho_{1} u_{1}^{2},
$$

where $\gamma$ is a heat capacity ratio, $\rho_{1}$ is gas density, $u_{1}$ is a shock wave speed.

Thus, a reason of the pressure ratio reduction for the discharge in hydrogen is connected with the low density of hydrogen in comparison with the density of oxygen or nitrogen. So, the density of oxygen is 16 times higher than the density of hydrogen at standard conditions. But the reduced density is compensated by the increased shock wave speed for the discharge in hydrogen. So, the shock wave speed is about $4000 \mathrm{~m} / \mathrm{s}$ at time of $1 \mu \mathrm{s}$ for the discharge in oxygen and the wave speed is about $2000 \mathrm{~m} / \mathrm{s}$ at such a time for the discharge in hydrogen. Thus the shock wave speed increased by 2 times and we have a well correlation of the pressure rise by equation (6) with change the density and the wave speed.

Comparison of the temperature distribution during the spark expansion in the various gases is given in Fig. 5. A rise in intensity of the spark channel expansion causes a fall in the gas temperature.

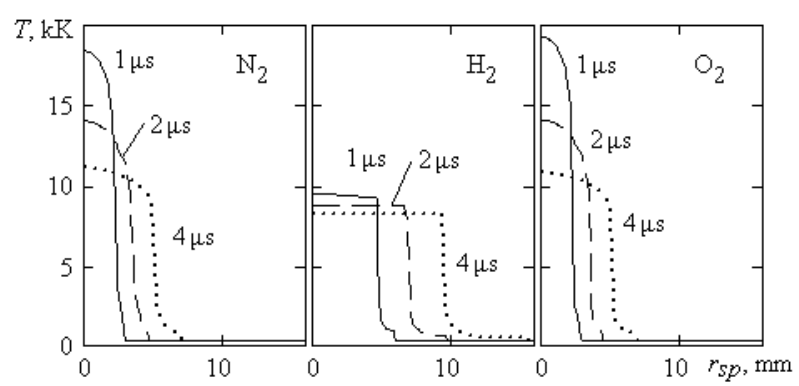

Fig. 5. Distribution of temperature along the radial coordinates at time of 1,2 , and $4 \mu$ for discharges in nitrogen, hydrogen and oxygen

So, a maximum of temperature located near axis of the spark channel is about $19.000 \mathrm{~K}$ at the time of $1 \mu \mathrm{s}$ for discharge in oxygen. The radius of the currentconducting channel is about $2 \mathrm{~mm}$ at such a case. For comparison, a maximum of temperature is about $9.000 \mathrm{~K}$ for discharge in hydrogen at the time of $1 \mu \mathrm{s}$ and the channel radius is about $4.5 \mathrm{~mm}$. But during the spark expansion the gas temperature is variable in a wide range for discharges in nitrogen and oxygen, falling from $15.000 \ldots 19.000 \mathrm{~K}$ at time of $1 \mu \mathrm{s}$ to $9.000 \ldots 11.000 \mathrm{~K}$ at time of $4 \mu \mathrm{s}$. For discharge in hydrogen, the temperature of the current-conducting channel is from $8.500 \ldots 9.500 \mathrm{~K}$ at time from 1 to $4 \mu \mathrm{s}$.

Results of the density history into the spark channel for discharges in nitrogen, hydrogen and oxygen are presented in Fig. 6.

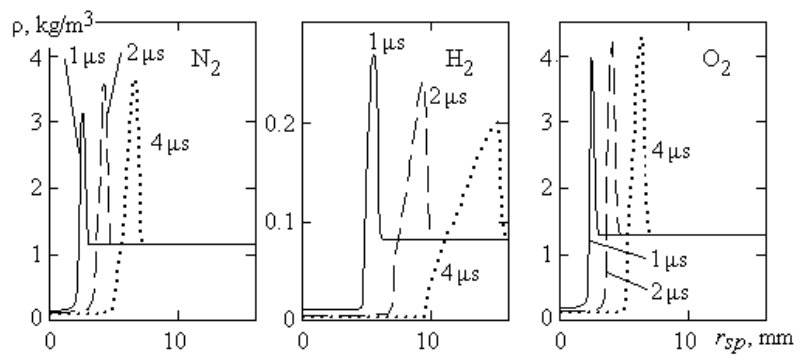

Fig. 6. Distribution of gas density along the radial coordinates at time of 1,2 , and $4 \mu$ s for discharges in nitrogen, hydrogen and oxygen

The density distribution allows analyzing a detachment of the shock wave from the current-conducting channel because a region of the low density corresponds to the channel and a region of the density rise reflects a location of the shock wave. It is observed that the detachment process is accelerated for discharge in hydrogen if we compare this process for discharges in nitrogen and oxygen.

Distribution of gas conductivity along the radial coordinates at the various times for discharges in nitrogen, hydrogen and oxygen is presented in Fig. 7.

It is observed reduced gas conductivity for discharge in hydrogen in comparison with the conductivity for discharge in nitrogen and oxygen. The reduced conductivity caused by the decreased gas temperature in the current-conducting channel.

The obtained results allow determining an influence of initial species concentration in mixture of nitrogen, hydrogen and oxygen on detonation initiation by spark discharge. 

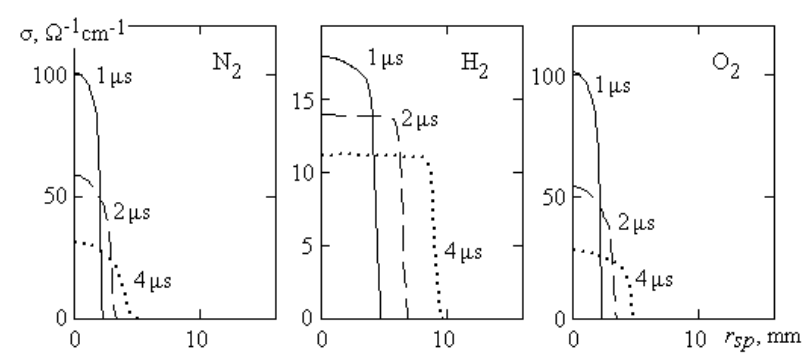

Fig. 7. Distribution of gas conductivity along the radial coordinates at time of 1,2 , and $4 \mu$ s for discharges in nitrogen, hydrogen and oxygen

Growth in the hydrogen concentration leads in particular to a rise in the energy input by spark discharge. An intensive detachment of the shock wave from the current-conducting channel for discharge in hydrogen promotes to start the oxidation chemical reactions.

\section{CONCLUSIONS}

Numerical investigation of spark channel expansion in hydrogen, oxygen and nitrogen allows determining changes in the energy deposition and the spatial distribution of the thermodynamic gas parameters during the spark evolution. It was found out that the current did not depend significantly on a type of gas. An increased energy deposition happens for discharge in hydrogen in comparison with discharges in nitrogen and oxygen. The highest pressure ratio in the shock wave front at the same time takes place for the spark expansion in oxygen and the lowest pressure ratio is exceeded for the discharge in hydrogen. A rise in intensity of the spark channel expansion causes a fall in the gas temperature. It is observed reduced gas conductivity for discharge in hydrogen in comparison with the conductivity for discharge in nitrogen and oxygen.

The obtained results can be used to determine an influence of initial species concentration in mixture of nitrogen, hydrogen and oxygen on detonation initiation by spark discharge.

\section{REFERENCES}

1. Yu. Shebeko, S. Tsarichenko, A. Trunev, A. Kaplin, A. Zaitsev. Investigation of the combustion characteristics of $\mathrm{H}_{2}-\mathrm{O}_{2}-\mathrm{N}_{2}-\mathrm{H}_{2} \mathrm{O}$ mixtures under elevated pressures and temperatures // Combustion, Explosion and Shock Waves. 1994, v. 30, p. 15-18.

2. V. Kamenskihs, H.D. Ng, J.H.S. Lee. Measurement of critical energy for direct initiation of spherical detonations in stoichiometric high-pressure $\mathrm{H}_{2}-\mathrm{O}_{2}$ mixtures // Combustion and Flame. 2010, v. 157, p. 1795-1799.

3. K. Korytchenko, S. Tomashevskiy, et al. Numerical investigation of energy deposition in spark discharge in adiabatically and isothermally compressed nitrogen // Japanese Journal of Applied Physics. 2020, v. 59, № SH.

4. Y. Tanaka, T. Michishita, Y. Uesugi. Hydrodynamic chemical non-equilibrium model of a pulsed arc discharge in dry air at atmospheric pressure // Plasma Sources Science and Technology. 2005, v. 14, p. 134148.

5. Y. Tanaka, T. Sakuta. Modelling of a pulsed discharge in $\mathrm{N}_{2}$ gas at atmospheric pressure // Journal of Physics D: Applied Physics. 1999, v. 32, p. 3199.

6. K. Korytchenko, S. Essmann, D. Markus, U. Maas, E. Poklonskii. Numerical and Experimental Investigation of the Channel Expansion of a Low-Energy Spark in the Air // Combustion Science and Technology. 2019, v. 191, p. 2136-2161.

7. K. Korytchenko et al. Validation of the numerical model of a spark channel expansion in a low-energy atmospheric pressure discharge // Problems of Atomic Science and Technology. 2019, № 1(119), p. 144-149.

8. The Chemkin thermodynamic database // ui.adsabs.harvard.edu > abs > abstract.

Article received 16.10.2020

\section{СРАВНЕНИЕ РАСШИРЕНИЯ ИСКРОВОГО КАНАЛА В ВОДОРОДЕ, КИСЛОРОДЕ И АЗОТЕ}

\section{К.В. Корытченко, Ю.В. Кашанский, О.В. Черкашин, Д.Ю. Белюченко, А.В. Максимов, А.И. Никорчук, П.В. Черненко}

Представлены результаты моделирования расширения искрового канала в различных газах, таких как водород, кислород и азот. Учтено различие в термодинамических свойствах различных газов. Выявлено влияние типа газа на разрядный ток, искровое сопротивление, энергию, вложенную в искру, и газодинамическое расширение искры. Обсуждено влияние начальной концентрации частиц в смеси азота, водорода и кислорода на инициирование детонации искровым разрядом.

\section{ПОРІВНЯННЯ РОЗШИРЕННЯ ІСКРОВОГО КАНАЛУ У ВОДНІ, КИСНІ ТА АЗОТІ}

\section{К.В. Коритченко, Ю.В. Кашанський, О.В. Черкашин, Д.Ю. Белюченко, А.В. Максимов, А.І. Нікорчук, П.В. Черненко}

Представлені результати моделювання розширення іскрового каналу в різних газах, таких як водень, кисень і азот. Враховано відмінність у термодинамічних властивостях різних газів. Виявлено вплив типу газу на розрядний струм, іскровий опір, енергію, вкладену в іскру, і газодинамічне розширення іскри. Обговорено вплив початкової концентрації частинок у суміші азоту, водню і кисню на ініціювання детонації іскровим розрядом. 